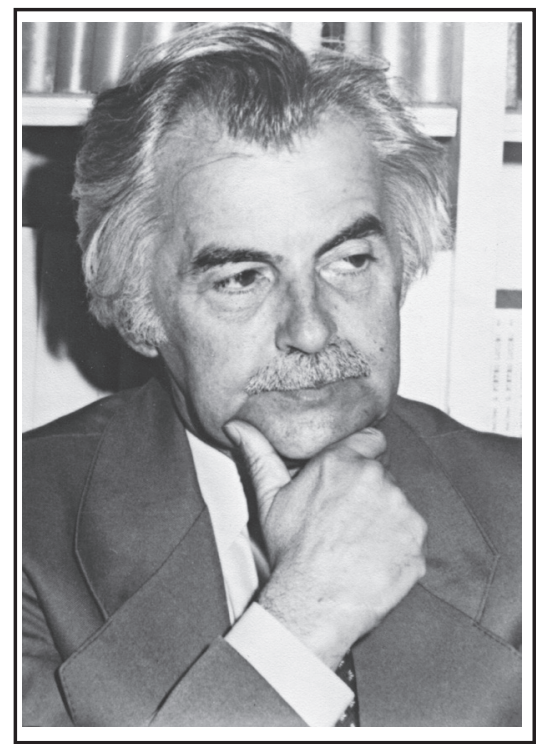

\title{
ПАМЯТИ МИЛАНАГЮРЧИНОВА
}

\section{IN MEMORIAM OF MILAN ǴURČINOV}

Настоящий номер готовился в честь 90-летнего юбилея македонского ученого академика Милана Гюрчинова выдающегося представителя современной филологии, слависта, македониста, компаративиста, исследователя и популяризатора русской классической и современной литературы у себя на родине. Однако накануне выхода номера, 25 июля, пришло скорбное известие, что после тяжелой и недолгой болезни

Милан Гюрчинов скончался.

Наука понесла невосполнимую утрату.

Редколлегия выражает соболезнование его семье, близким и коллегам.

Вечная память славному сыну македонского народа, просветителю и неутомимому труженику науки.

\section{Слово о Милане Гюрчинове}

\section{A Word about Milan Ǵurčinov}

25 июля 2018 г. скончался Милан Гюрчинов. 28 июля он должен был отметить славный юбилей - 90 лет. Человек блестящей эрудиции, обладающий в гуманитарной сфере поистине энциклопедическими познаниями, славный представитель интеллектуальной элиты своего народа, он внес бесценный вклад в современную науку о литературе. Его перу принадлежат около тридцати фундаментальных исследований по актуальным вопросам теории и истории славянских литератур, в первую очередь по молодой, но имеющей древние корни македонской литератуpe. М. Гюрчинов является основоположником нескольких национальных научных литературоведческих школ: литературоведческой компаративистики и македонской литературоведческой русистики. За огромный личный вклад в популяризацию и исследование русской культуры у себя на родине ученый был удостоен государственной награды России - Медали имени А.С. Пушкина.

М. Гюрчинов представитель того поколения национальной интеллигенции, которое с честью выполнило высокую миссию по формированию во второй половине XX в. современного типа македонской культуры. После 1945 г., когда за македонским народом было признано право на национальную идентичность, стали бурно развиваться основные области национальной культуры, была оформлена литературная норма македонского языка, национальное искусство слова демонстрировало количественный и качественный рост. В этом сложнейшем процессе 
М. Гюрчинов всегда принимал самое деятельное участие на протяжении более чем шестидесяти лет. Эта задача требовала колоссального трудолюбия и универсальных способностей. В разностороннней личности М. Гюрчинова соединились вкус и интуиция литературного критика, настойчивость исследователя, талант университетского профессора и незаурядные организаторские качества.

М. Гюрчинов родился 28 июля 1928 г. в Белграде в семье инженера. Родители рано умерли, но успели дать детям хорошее воспитание и привили тягу к знаниям. Дорогу в жизни М. Гюрчинов прокладывал самостоятельно. Преодолевая опасности военного времени и голодные послевоенные годы, он закончил гимназию и сделал шаг, определивший его судьбу, - начал изучать филологию на философском факультете университета в Скопье. Затем он перевелся в Белградский университет, где закончил группу русского языка и литературы отделения славянской филологии (1951). Это были очень сложные годы, отмеченные конфликтом между Югославией и СССР (1948-1953), который привел к разрыву отношений между странами ${ }^{1}$. В такой полной драматизма обстановке М. Гюрчинов начал свой путь в науку, постигая тайны профессии под руководством выдающихся педагогов и ученых, среди которых был, например, К.Ф. Тарановский. Память об этом замечательном человеке М. Гюрчинов сохранил на всю жизнь, как и благодарное отношение ко всем своим учителям.

К.Ф. Тарановский - ученый с мировым именем - сыграл важную роль в формировании белградской школы русистики, в том числе в постижении опыта дореволюционных российских школ академического литературоведения. М. Гюрчинов, таким образом, приобщился к мощной научной традиции и получил серьезную фундаментальную подготовку, которая позволила ему успешно реализоваться в разных областях филологии и всемерно содействовать формированию национального литературоведения и литературной критики. Он рано понял, что ни одна национальная литература не замыкается в своих рамках и что ее эффективное развитие напрямую связано с успешным синтезом национальной традиции, национального видения мира и способностью творчески воспринимать богатство мирового искусства слова. Это же суждение он повторил, опираясь на приобретенный богатейший опыт, много лет спустя в выступлении на съезде писателей Югославии, незадолго перед распадом союзного государства (апрель 1985, Нови Сад) и привел в книге воспоминаний «Постижение действительности» (2000): «Я не верю, что национальная идентичность может пострадать, если она будет жить и развиваться в открытом культурном и духовном пространстве. Напротив, я думаю и даже глубоко убежден, что только открытость может способствовать проявлению национальной идентичности в полной мере»².

С таким пониманием искусства слова М. Гюрчинов вступил в 1953 г. на поприще национальной литературной критики - как раз тогда, когда эта критика только начала по-настоящему рождаться и развивать собственное понимание литературы, став ареной столкновений между сторонниками разных подходов к оценке художественного произведения. М. Гюрчинов активно участовал в литературных дискус-

\footnotetext{
${ }^{1}$ В 1948-1953 гг. были разорваны все отношения с Югославией (экономические, межпартийные и дипломатические). Это период вошел в историю как «время Информбюро». По инициативе Сталина орган Коминтерна - Международное Информационное бюро коммунистических и рабочих партий принял в июне 1948 г. резолюцию «О ситуации и положении в КПЮ», содержащую критику руководства КПЮ. Дипломатичпеские отношения с СССР были восстановлены только после смерти Сталина, а нормализация отношений произошла после визита в Белград Н.С. Хрущева в 1955 г. - А.Ш. ${ }^{2}$ Гурччинов М. Освојување на реалноста. Скопје, 2000. С. 419.
} 
сиях, вырабатывая и совершенствуя собственные эстетические представления об искусстве и литературе. Его дебют как литературного критика тесно связан с журналом «Млада литература», где он опубликовал свой первый критический опус «Стихи и тревожные чувства» («Стихови и неспокојства», 1953), посвященный сборнику стихотворений «Тревожные звуки» Гане Тодоровского, поэта, который внес большой вклад в обогащение поэтического языка македонской лирики. В этом эссе автор показал себя единомышленником молодых писателей, выступавших за равноправие идейного и художественного аспектов в художественном творчестве и за широкое использование мирового художественного опыта. С этого времени М. Гюрчинов стал одним из самых активных участников национального литературного процесса. Он писал критические отзывы о важнейших литературных событиях - изданиях новых произведений, свидетельствующих об интенсивном развитии молодой литературы (Г. Ивановском, К. Чашуле, С. Яневском, Й. Бошковском и др.). Самое пристальное его внимание было обращено на лирику и прозу выдающегося македонского писателя Б. Конеского, вступившего в пору творческого расцвета. Высокие оценки критика, как показало время, относились к вершинным достижениям национальной литературы: поэзии А. Шопова, М. Матевского, В. Урошевича, прозы В. Малеского, Д. Солева, Ж. Чинго, драматургии К. Чашуле, Б. Пендовского и многих других авторов и произведений.

Участие в национальном литературном процессе, работу литературного критика М. Гюрчинов совмещал с преподавательской и научной работой. Глубокое владение материалом текущего литературного процесса, соединенное с исследовательской деятельностью, помогло в работе над собственными обобщающими трудами. Монография «Время и художественное выражение: критика и очерки» («Време и израз: критики и огледи», 1956) стала событием в национальной науке о литературе. Событиями становилось большинство опубликованных автором книг. Назовем лишь некоторые: «Живое и мертвое» («Живо и мртво», 1974), «Взаимопроникновения: возможности компаративного изучения нашей литературы» («Прожимања: могућности компаративног проучавања наше књижевности» (на сербском яз.; 1990), «Сравнительно-исторические исследования» («Компаративни студии», 1998). М. Гюрчинову принадлежит первая в национальной филологии попытка систематического концептуального осмысления истории македонской литературы XX в.: «Новая македонская литература: 1945-1980 гг.» («Nova makedonska književnost: (1945-1980)»; Белград, 1988).

Сочетать работу литературного критика с преподавательской деятельностью М. Гюрчинов стал еще в 1953 г., начав работать на философском (позднее филологическом) факультете университета в Скопье, где в течение двадцати лет он преподавал русскую литературу XIX-XX вв. Когда во второй половине 1950-х гг. отношения между СССР и Югославией нормализовались, он в составе первой группы югославских ученых приехал на стажировку в Московский университет для подготовки докторской диссертации «Переломные годы в жизни и творчестве А.П. Чехова» (о творчестве писателя второй половины 1880-х - начала 1890-х гг.). В Москве его научным консультантом был выдающийся ученый филологического факультета, известный теоретик литературы профессор Г.Н. Поспелов. Через несколько лет М. Гюрчинов специализировался в Сорбонне (1960-1961), где постигал тонкости компаративистского подхода к искусству слова и существенно расширил свои представления о русской литературе XX в. за счет знакомства с авторами и произведениями, которые замалчивались тогдашней литературной наукой (эмигрантская литература и ряд авторов и текстов русских нереалистических течений). 
М. Гюрчинов после своей первой поездки еще много раз бывал в нашей стране, он установил многочисленные профессиональные контакты с российскими литераторами и учеными. Докторскую диссертацию М. Гюрчинов защитил в 1960 г. в университете им. Свв. Кирилла и Мефодия в Скопье, где был в 1972 г. избран на должность профессора университета. Глубокие и систематические познания македонского ученого в области русской литературы отражены в его многочисленных трудах, посвященных самым разным аспектам и авторам. Кроме творчества Чехова он глубоко интересовался творчеством Достоевского и Пастернака, о которых написал исследования, заставившие обратить на него внимание в научных кругах Югославии, других странах Европы и России.

Признание и известность в области русистики и компаративистики М. Гюрчинову принесла монография о творчестве Б. Пастернака («Б.Л. Пастернак», 1987). Он также автор монографий «Ф.М. Достоевский» (1981), «Носители гуманизма и человечности: очерки о русских писателях» («Заговорници на човечността (огледи за руски писатели)», 1992), исследователь Блока, Горького, Есенина, Шолохова. Особое внимание посвятил М. Гюрчинов изучению русского литературного авангарда, в том числе творчеству В. Маяковского. В работе «Сравнительные исследования» (1998) важное место принадлежит вопросам влияния русской литературы на развитие македонского искусства слова, освещены основные этапы и особенности этого процесса. Подчеркнута роль творческого импульса Достоевского, Чехова, Маяковского, Есенина, Пастернака, Шолохова, Платонова, Цветаевой, Аксенова, Вознесенского для становления и развития национальной литературы. Отдельное внимание уделено влиянию теоретических воззрений М. Бахтина на развитие литературоведческой мысли в Югославии, в том числе в македонской литературоведческой науке. Монография М. Гюрчинова «Гармония в хаосе. Русская литературная классика и модерн» («Хармонија во хаосот. Руска книжевната класика и модерна», 2004) ключает исследования творчества выдающихся русских писателей XIX-XX вв. - от Пушкина до Вознесенского, объединенные философским и эстетическим принципом - поиском идеала прекрасного и гармонии во враждебном человеку мире. Основополагающее для подлинного искусства, это начало обнаруживается исследователем в произведениях как классической, так и современной русской литературы. Ее высокий гуманистический пафос неизменно выносится М. Гюрчиновым на первый план.

Критические работы М. Гюрчинова переведены на сербский, хорватский, русский, французский, английский языки. В 1993 г. во Франции был издан его труд «Пастернак и Маяковский».

С докладами по проблемам изучения русской литературы в течение нескольких десятилетий ученый выступал на крупных международных научных форумах и мероприятиях, в том числе организованных ЮНЕСКО (во Франции, Англии, Осло и др.), и Международных съездах славистов. С 2003 по 2008 г. он был председателем международного комитета славистов и возглавлял подготовку к XIV съезду славистов, который прошел в Охриде (2008). Неоднократно принимал участие в научных конференциях в Москве и Петербурге. М. Гюрчинов был одним из инициаторов проведения регулярных русско-македонских конференций (к настоящему времени их уже проведено семь), в которых участвовали сотрудники университетов Македонии, Македонской Академии наук и искусств, Института славяноведения РАН, преподаватели филологического факультета МГУ имени М.В. Ломоносова, слависты из Пермского и Воронежского университетов. 
Неутомимый популяризатор русской культуры, М. Гюрчинов был организатором празднования в Македонии юбилеев и памятных дат русских писателей (Достоевского, Чехова, Пушкина, Пастернака). Под его редакцией изданы на македонском языке собрания сочинений Пушкина, Достоевского, Чехова, Пастернака.

М. Гюрчинов воспитал не одно поколение специалистов в области русского языка и литературы. Под его руководством были защищены многочисленные кандидатские и докторские диссертации (Д. Ристеский, С. Стойменска-Эльзессер и др.). В 1980 г. он стал основателем и первым заведующим кафедрой (1980-1985) сравнительного литературоведения филологического факультета университета в Скопье, где выросло целое поколение исследователей-компаративистов (Е. Шелева, Д. Дурацовский, А. Прокопиев и др.).

Академик Македонской Академии наук и искусств (с 1988 г.), М. Гюрчинов до последних дней продолжал свою неутомимую деятельность в самых разных областях. Он входил в Европейское Общество по культуре «S.Е.С.» (Венеция), являлся членом Mediterrannean Academy (Неаполь). Как член Союза писателей Македонии был председателем международного поэтического фестиваля «Стружские вечера поэзии», известного далеко за пределами Македонии. Возглавив писательскю делегацию Македонии во время поездки в Москву в 1981 г., он участвовал в проведении круглого стола «Война в произведениях советских и югославских писателей».

Плодотворная деятельность М. Гюрчинова отмечена многочисленными наградами на родине ученого и за ее пределами.

Вечная память самоотверженному труженику науки, выдающемуся ученому, глубокому исследователю и почитателю русской культуры - Милану Гюрчинову. 